\title{
USE OF SOCIAL MEDIA IN COMMUNICATION STRATEGIES OF PREMIER LEAGUE FOOTBALL CLUBS
}

\author{
Maja Obradovići, *, \\ Slavko Alčaković ${ }^{1}$ \\ Daria Vyugina², \\ Sandra Tasevski ${ }^{1}$
}

\author{
'Singidunum University, \\ Belgrade, Serbia \\ ${ }^{2}$ Lomonosov Moscow State University, \\ Moscow, Russia
}

Correspondence:

Maja Obradović

e-mail:

mobradovic@singidunum.ac.rs

\begin{abstract}
:
Development of internet and new technologies leads to big changes in communications. Every sport organization is in search for the most efficient communication channel. In order to find the most efficient communication channel with the lowest cost, sport organizations have recognized the importance of social media networks in communication strategies. Being that social media networks can be considered as a source of information for customers, this article considers social media networks as one of the main tools used in sports branding and communication strategies due to its communicative, broadcasting, organizational and interactive potential. As a network with the higher number of active users, Facebook was the main network which has been analyzed. Using the example of Premier League football clubs, the authors analyzed the content of the most popular official Facebook pages dedicated to the English football clubs and tries to identify the key conditions for successful social media campaign. Results show that the top Premier League clubs are usually using four content formats combined with nine content types.
\end{abstract}

\section{Keywords:}

sports social media, digital consumption, sports branding, communication strategies in sports.

\section{INTRODUCTION}

In the world where there are 3.5 billion football fans -EU, Africa, Asia, America [1] one professional league stands out. The Premier league (UK football league) with projected revenue of 4.5 billion pounds in 2017 2018 season [2] marks the number one sport in professional football. None of the football clubs or organizations involved in the business of sport can forget the fundamental aim of every sport marketing activity: "satisfaction of every right consumer need with sports product or services that offer benefits better than all other competitors whilst making the maximum profit. [3].

A sport brand is no longer just a name or a symbol, colour, but a product of communication between the producer and the consumer, in the images, values and other characteristics that the audience of the stakeholders sees behind the brand. The image component of the brand allows to form the necessary projection of these values as a recognizable, value aspect of the brand in the mass consciousness. 
To reach sport fans, marketers are focusing their efforts on anything that brings them closer to the action and discussion. Sport organizations have been searching for more efficient channels to reach consumers with the lowest possible cost and the highest possible efficiency. [4] For industry of that size, challenge is to build a strong relation with every sport fan.

There are some main ideas that might support the communication strategy of any sports club brand in the digital world [5]. First of all, any sport brand seeking success should create newsbreak and interesting stories, provide the audience with a dramatic act, provoke emotional empathy, and make them participate in the main events. Secondly, it is important to involve new sponsorship in the process, educate the loyalty of the sponsors, and create an associative relationship between brands to make beneficial profit on the sports events. Also, due to the development of the digital technologies it becomes easier to organize and enlighten media and social projects, and control feedback of the audience, as far as interact with it actively.

A sport business needs to communicate with its customers (fans) in order to ensure that existing (and new) customers are aware of the sport, team or player, hold positive attitudes, have extensive and appropriate knowledge of the sport offering, and provide a source of revenue. [3] One of the best ways for the companies or sport organizations to meet their relationship marketing goals is using the benefits of the social media [6]. Social media is being used more frequently by sports organizations and athletes as a tool for communication. It allows consumers to interact on several levels. It permits interaction from consumers to consumers (between fans) and consumers to organizations. These interactions can develop into consumer experience. Social media could be seen as initial interaction with the purpose of transforming into a strong relationship.

Today, sport organizations are realizing the benefits of social media and they are seeking ways to most effectively use them as part of their overall marketing, communication, and brand-management strategies. [7] According to [8] there are many dimensions to relationship marketing, however social media provides the opportunity to focus on two out of three core components: communication and interaction. For those two purposes, most marketers recommend the most used social media platforms - Facebook, Instagram, Twitter. Facebook as the biggest media platform with over 2 billion monthly active users [9] will be the main focus of this article.
Most of the football clubs have recognized efficiency of social networks in communication strategies. Kuzma, Bell and Logue compared communication strategies of European football in four leagues. Overall, the research statistics showed that most teams do have some social media presence. In terms of official presence, Twitter was the surprise social network to have the widest spread usage, as every team bar one used it to communicate with fans. Facebook usage was also good, but there were four teams in the European leagues that did not have an official Facebook page. [10]

The media consumers are no longer passive users; their interaction with the information and content is quite active due to the newest technologies and access to the digital media gadgets. Due to opportunities of the multimedia technologies brand consumers can influence content, ad campaigns and events. Social media websites in this case can be introduced as the main instruments successful interaction. In addition, the establishment of a dialogue with the public is driven through the social media profile to explain its position on various sports, financial and legal issues. [11]

For sport fans, two screen experience has become crucial for their engagement, with the $76 \%$ of fans who watched sports on one screen, had the second screen active [12] allowing them to have a stronger relationship with their sports organizations. A second screen is a second electronic device used by television viewers to connect to a program they're watching. The thing about second screen is to make TV more interactive for viewers and create buzz on social media about program/ event. [13] Mostly, second screen is the mobile screen. According to SecondSync, fully $60 \%$ of the interactions around primetime programming take place during the broadcast. This is especially true of new status updates, or Posts, which tend to cluster within the live window. Reactions to those posts, such as likes and comments, have a longer tail. In aggregate, for the 10 different broadcasts included in the SecondSync study, Facebook users produced 9.9 million relevant posts and comments versus 5.1 million tweets. [14]

Facebook is an online social network launched in 2004. According to Statista, in the third quarter of 2017, Facebook had 2.07 billion monthly active users. [15] Mission of the Facebook is "bringing the world closer together" [16] The goal of the network is to connect and share information. Past research has shown that Facebook is used to provide information, post pictures and videos and promote upcoming events. Facebook's mission is to give a people the power to build a community 
and to connect and bring together people from different parts of the world in one place. By using Facebook, football clubs are attempting to take advantage of its capabilities, by keeping consumers aware and connected to the brand.

Current literature shows that there is no specific number of posts per day which will bring the best results. That depends of characteristics of fans/followers on Facebook. According to Social Bakers and their research, there is no exact ideal number, but there is a range. Typically, if you post fewer than 2 posts a week, you will not engage your audience enough for them to maintain a social connection with you, and you will lose engagement. If you post more than 2 per day (as a brand) you will typically lose engagement. [17] Additional research by Track Social says that when a brand posts twice a day, those posts only receive $57 \%$ of the likes and $78 \%$ of the comments per post. The drop-off continues as more posts are made in the day. [18]

Marketers agree that frequency of posting, time of posting and content itself are the most important elements of good communication strategy and interaction on social media.

The significance of this study is finding the right type of content which has ability to engage sport fans through social media.

\section{METHODOLOGY}

In order to answer which content has most success in communication strategies, conducted research analyzed Premier League clubs and their online communication channels. The research included monitoring of Facebook profiles of Premier League football clubs. Data was analyzed in April 2017, including weekends when clubs were the most active on social networks. Observation included analysis of twenty clubs of Premier League and identified five clubs with the higher number of fans. All data were collected from official Facebook profiles.

Research and results were divided in three categories: Type of content, Content format and Frequency of posting on Facebook.

Content is a compilation of information, ideas, and messages that are translated into some kind of written, visual, or audible format for others to consume. [19] Type of content defines a category of published posts and what are posts about. Usually posts are published in link, photo or video format. Frequency of posting is showing a number of posts which are published in some period of time.

\section{RESULTS AND DISCUSSION}

Results of conducted research are showing a way of using social media as a marketing tool in sport industry through the type of content which has been posted and has engaged the most fans.

Table 1. Number of Facebook fans - top 5 premier league clubs

\begin{tabular}{ccc}
\hline No & Team & Facebook \\
\hline 1 & Manchester United & 73.018 .132 \\
\hline 2 & Chelsea & 47.789 .562 \\
\hline 3 & Arsenal & 37.854 .441 \\
\hline 4 & Liverpool & 29.751 .065 \\
\hline 5 & Manchester City & 23.656 .473 \\
\hline
\end{tabular}

According to Table 1, from data which has been collected from official football club profiles on social networks, Manchester United, Chelsea and Arsenal are clubs with the higher number of likes/ fans on Facebook.

First category which has been analyzed was content. In the period of observation, entire content which has been posted was sorted in nine categories. Categories were formed to give a complete insight in online communication strategies of football clubs with their fans. Categories were formed depending on what they are talking about- is it about game, interesting information or promotion activities and sponsorship which is not directly connected with football.

Content which has been posted was analyzed and grouped in nine categories:

1. Game announcements

2. About game (new/live info)- team members on field, changes and injuries, scored goals

3. The best moments (from the game)- the most attractive moves, goals, score

4. Players and coach announcements/interviews

5. Behind the scene- players on training, arrivals to stadium, hanging out and stories from the locker room

6. Interesting facts/info about players and club- past event reminders in history of club, player birthdays and interesting statistics

7. Fan support- arrivals to stadium and cheer/support

8. Promotion activities which are not directly connected with football- charity events and ceremony

9. Sponsors and partner promotions 
According to Table 2. Manchester United gives the most attention to content categorized as Game announcement and Players and coach announcements/ interviews. These two categories together make about $50 \%$ of all Facebook posts in period of observation. Type of content with the lowest percentage in all Facebook posts categories are Sponsors and partner promotions and Promotion activities which are not directly connected with football. Chelsea has no posts from the lastmentioned categories.

Announcements which are directly connected to game- live info, the best moments and game announcements are necessarily/ required part of communication strategies for all clubs and they make a $1 / 3$ of all posts. On the other side, on the day when there is no game on, posts like. Behind the scene and Players \& coach announcements/ interviews had a lead role.

Interesting is that even the game is the main attraction of clubs, only $1 / 3$ announcements are directly connected with them, and even $50 \%$ or over $60 \%$ of posts are related to atmosphere, club activities and they don't need to necessarily be connected to the game. This could be explained with the fact that the games are playing only once or twice a week but clubs are interested in everyday communication and interaction with their fans.

In addition to everything mentioned above also it should pay attention to format of content. Content was categorized in four types- photo, video, link and text.

\section{Content format}

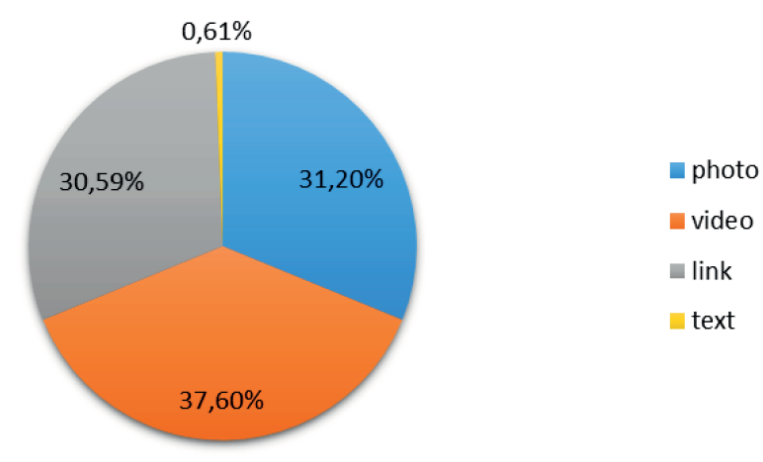

Graph 1. Content format posted on Facebook

According to research results, video is taking lead as type of content format with almost $38 \%$. Posts with photo and link are almost equally distributed (around $31 \%)$. Link means any post with link which redirect to another web page. Most often, that redirect leads consumer directly to official football club website. This can be interpreted as an attempt of clubs to increase number of unique visits to the official site, which includes links to their online stores, as well as links to sponsors.

Table 2. Facebook content analysis

\begin{tabular}{|c|c|c|c|c|c|}
\hline Content type/category & Manchester United & Chelsea & Arsenal & Liverpool & Manchester City \\
\hline Game announcements & $20,71 \%$ & $8,70 \%$ & $6,86 \%$ & $11,28 \%$ & $15,79 \%$ \\
\hline About game (new/live info) & $8,08 \%$ & $10,14 \%$ & $5,88 \%$ & $6,77 \%$ & $7,89 \%$ \\
\hline $\begin{array}{l}\text { The best moments (from the } \\
\text { game) }\end{array}$ & $8,59 \%$ & $5,80 \%$ & $13,73 \%$ & $12,03 \%$ & $10,53 \%$ \\
\hline $\begin{array}{l}\text { Players and coach announce- } \\
\text { ments/ interviews }\end{array}$ & $29,29 \%$ & $23,19 \%$ & $29,41 \%$ & $28,57 \%$ & $19,30 \%$ \\
\hline Behind the scene & $6,57 \%$ & $11,59 \%$ & $7,84 \%$ & $8,27 \%$ & $9,65 \%$ \\
\hline $\begin{array}{l}\text { Interesting facts/info about play- } \\
\text { ers and club }\end{array}$ & $19,19 \%$ & $39,13 \%$ & $29,41 \%$ & $24,06 \%$ & $29,82 \%$ \\
\hline Fan support & $1,52 \%$ & $1,45 \%$ & $1,96 \%$ & $3,76 \%$ & $4,39 \%$ \\
\hline $\begin{array}{l}\text { Promotion activities which are } \\
\text { not directly connected with } \\
\text { football }\end{array}$ & $4,04 \%$ & $0 \%$ & $0,98 \%$ & $2,26 \%$ & $0,88 \%$ \\
\hline Sponsors and partner promotions & $2,02 \%$ & $0 \%$ & $3,92 \%$ & $3,01 \%$ & $1,75 \%$ \\
\hline
\end{tabular}


Average number of Facebook posts per day

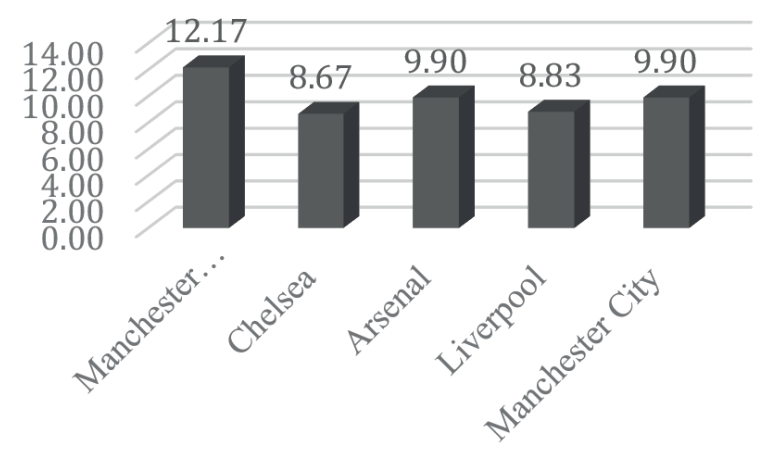

Graph 2. Review of the average number of published Facebook posts per day

Graph 1 shows the average number of Facebook posts per day in observed period for top five clubs. Manchester United has around 12, 17 posts, Manchester city and Arsenal has almost equal number of posts $(9,90)$, and Chelsea and Liverpool have no posts so often $(8,67)$. Analyzed Facebook pages of football clubs are popular and followed from people all over the world, so they have published posts in different time of day, according to different time zones of fans.

\section{CONCLUSION}

Social media might be effectively used in communication strategies and developing of the sports brands due to several reasons that were indicated in this article. Multimedia content makes the experience of the audience more diversified and complete; as one of the main informational sources for all the media consumers today, it creates the sports agenda. Also, it opens up new ways to reach new sponsors that might not be found in the "offline"; and becomes the easiest and the fastest way to interact with the audience, to deliver content personally.

The paper presented analysis of Facebook pages and content which has been posted on official profiles of Premier League clubs. After the conducted research and interpreted results authors come to conclusion that a carefully created communication strategy is very important when it comes to communication with followers / fans on social networks.

The most popular social media network among the researched is Manchester United Facebook page. It happens due to several facts that are not caused by the historical popularity of this football club. Its online success depends on the highest number of posts created and published every day, the type and variety of content, mostly dedicated to the club, its games, players and coaches - a kind of closer look at the team, its everyday life and history that creates the uniqueness of this club as a famous sports brand.

As a result, according to the previous research, the most important managerial implication suggests that number of fans (i.e., brand reach) is the most important social media indicator because it is correlated with several other indicators (i.e., brand growth and engagement). Therefore, leading brands in sports industry should as their primary goal strive towards maximizing fan base. [4].

Also, when it comes to frequency of communicating with fans through the social media networks, clubs need to have in mind that they need to continue with everyday interaction. Crucial is to communicate continuously, every day, not just on days when club is playing a game. Social media profiles created by clubs should be the source of information for fans about events important for club. Also, it need to be considered that content needs to be focused on game results, success of the team, but also on players individually, the history of the team and interesting facts about club and team- as a content with the higher interaction (according to research).

\section{REFERENCES}

[1] TopEndSPorts. (2016). Top 10 List of the World's Most Popular Sports. Retrieved from Top end sports: http://www.topendsports.com/world/lists/ popular-sport/fans.htm

[2] Deloitte (2017). Annual review of football finance. Sport and Business group. Retrieved from https:// www2.deloitte.com/uk/en/pages/sports-businessgroup/articles/annual-review-of-football-finance. html

[3] J. Beech, S. Chadwick, The Business of Sport Management, Pearson Education, 2004.

[4] V. Podobnik, An Analysis of Facebook Social Media Marketing. 12th International Conference on Telecommunications. Zagreb. 2013

[5] V. Kostikov, Brend sportivnogo kluba kak kommunikativnaya konstruktsiya [Sports Club Brand as a Communicative Structure]. Mediaskop4. (in Russian): http://www.mediascope.ru/2373, 2017.

[6] J.Williams \& S. Chinn, Meeting relationship marketing goals though social media: A conceptual model for sport marketers. International journal of sport Communication, 3, 2010., pp. 422-437. 
[7] P. Coyle, Teams active in social media build strategic advantage. Street \& Smith's SportsBusiness Journal, 2010.

[8] Gronoos. The relationship marketing process: Communication, interaction, dialogue, value. Journal of Business and Industrial Marketing, 19(2), 2004., pp. 99-113.

[9] Zephoria. Top 15 valuable Facebook statistics. Retrieved in 2018 from Zephoria: https://zephoria. com/top-15-valuable-facebook-statistics/

[10] J. Kuzma, V. Bell, C. Logue, A study of the use of social media marketing in the football industry. Journal of emerging trends in computing and information sciences, 2014., pp 728-738

[11] I. Yavlenin, Sports marketing: the principles of a professional sports club positioning. The Encyclopedia of marketing: http://www.marketing.spb.ru/ lib-special/branch/sport.htm, 2008.

[12] M. Romanovsky, How Marketers Are Reaching Out To Sports Fans In A Mobile-First Era. Retrieved from Forbes.com: https://www.forbes.com/sites/ forbescommunicationscouncil/2017/08/23/howmarketers-are-reaching-out-to-sports-fans-in-amobile-first-era/\#4ddf87177a0a
[13] Tehnopedia Retrieved from Tehnopedia: www. techopedia.com

[14] J. Bercovici, Who Rules The Second Screen, Facebook Or Twitter? Retrieved from Forbes: www.forbes. com

[15] Statista Retrieved from Statista: https://www.statista.com/topics/751/facebook/

[16] Facebook, Retrieved from Facebook: www.facebook.com

[17] SocialBakers, How often should you post on your Facebook pages? Retrieved from https://www.socialbakers.com/blog/147-how-often-should-you-poston-your-facebook-pages

[18] BufferSocial, Retrieved from https://blog.bufferapp. com/social-media-frequency-guide

[19] L. Odden What is Content? Learn from 40+ Definitions. Retrieved from TopRank Marketing Blog: http://www.toprankblog.com/2013/03/what-is-content/ 